\title{
Radiocarbon Dates from Aboriginal Sites in Cherokee, Henderson, and Tyler Counties in East Texas
}

Timothy K. Perttula

Heritage Research Center, Stephen F. Austin State University

Follow this and additional works at: https://scholarworks.sfasu.edu/ita

Part of the American Material Culture Commons, Archaeological Anthropology Commons, Environmental Studies Commons, Other American Studies Commons, Other Arts and Humanities Commons, Other History of Art, Architecture, and Archaeology Commons, and the United States History Commons

Tell us how this article helped you.

This Article is brought to you for free and open access by the Center for Regional Heritage Research at SFA ScholarWorks. It has been accepted for inclusion in Index of Texas Archaeology: Open Access Gray Literature from the Lone Star State by an authorized editor of SFA ScholarWorks. For more information, please contact cdsscholarworks@sfasu.edu. 


\section{Radiocarbon Dates from Aboriginal Sites in Cherokee, Henderson, and Tyler Counties in East Texas}

\section{Creative Commons License \\ (c) (i) (8)}

This work is licensed under a Creative Commons Attribution-NonCommercial 4.0 International License 


\title{
Radiocarbon Dates from Aboriginal Sites in Cherokee, Henderson, and Tyler Counties in East Texas
}

\author{
Timothy K. Perttula
}

\section{Introduction}

The newly obtained radiocarbon dates discussed in this article were done by DirectAMS of Seattle, Washington. Three of the sites have only a single AMS radiocarbon date, while four radiocarbon dates have been obtained from the M. S. Roberts site (41HS8) on Caddo Creek in the Neches River basin. The radiocarbon ages obtained on these samples have been calibrated to 2 sigma using IntCal 13 (Reimer et al. 2013). These dates were obtained to continue to expand the utility of the East Texas Radiocarbon Database to better understand the age of archaeological components at sites in the region, as well as ascertain temporal trends in settlement by Native Americans in East Texas (cf. Selden 2012; Selden and Perttula 2013a, 2013b).

\section{George C. Davis (41CE19)}

The new radiocarbon date from the George C. Davis site is on a piece of carbonized cane stem from a concentration of carbonized cane (Figure 1) recovered in the WPA excavations in Unit 26R9, 20-25 inches (ca. 51-64 cm bs) below the surface. This unit falls within the limits of Feature 18 (Newell and Krieger 1949:30 and Figure 4), one of a number of overlapping circular structures east of Mound A at the site. The depth of the sample is at the same depth at which post holes to the structures were first exposed (i.e., 20 inches below surface).

The conventional radiocarbon age of the sample of charred cane is $721 \pm 23$ years B.P. (D-AMS 15383). The 2 sigma calibration ranges from A.D. 1264-1290. This calibrated date does fall within the summed probability distribution of the more than 100 radiocarbon dates obtained from the George C. Davis site (Figure 2), although it is towards the end of the principal ancestral Caddo occupation there.

\section{Bowles Creek (41CE475)}

The new radiocarbon date from the Bowles Creek site came from charred Carya sp. nutshells recovered from the fill (60-72 cm bs) of Stain 5, a post hole exposed in Unit BC-2 (Perttula and Stingley 2017). the conventional radiocarbon age is $378 \pm 28$ years B.P. (D-AMS 15385). The 2 sigma calibrated age range of the charred nutshells is A.D. 1446-1632, dating the post hole fill to the Late Caddo period Frankston phase.

An earlier date on a piece of unburned animal bone from Unit 3,40-50 cm bs at the site was $410 \pm$ 24 years B.P. (D-AMS 11799), or A.D. $1540 \pm 24$. The 2 sigma calibration (95 percent probability) of this radiocarbon age is A.D. $1525 \pm 84$. The mean 2 sigma calibrated age range of the two radiocarbon dates from the Bowles Creek site is A.D. 1443-1618. 


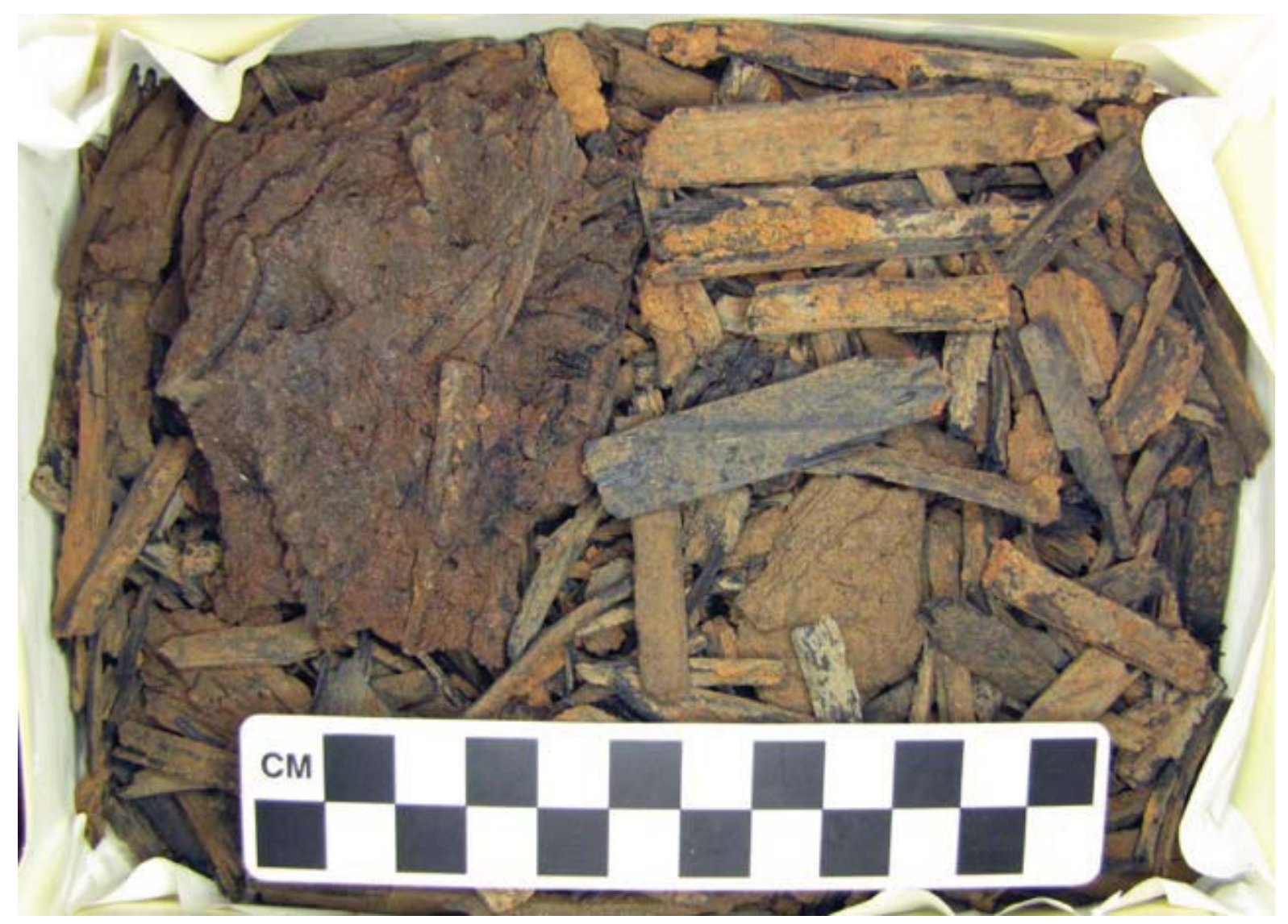

Figure 1. Carbonized cane stems from Unit 26R9 (Lot 3137a) at the George C. Davis site.

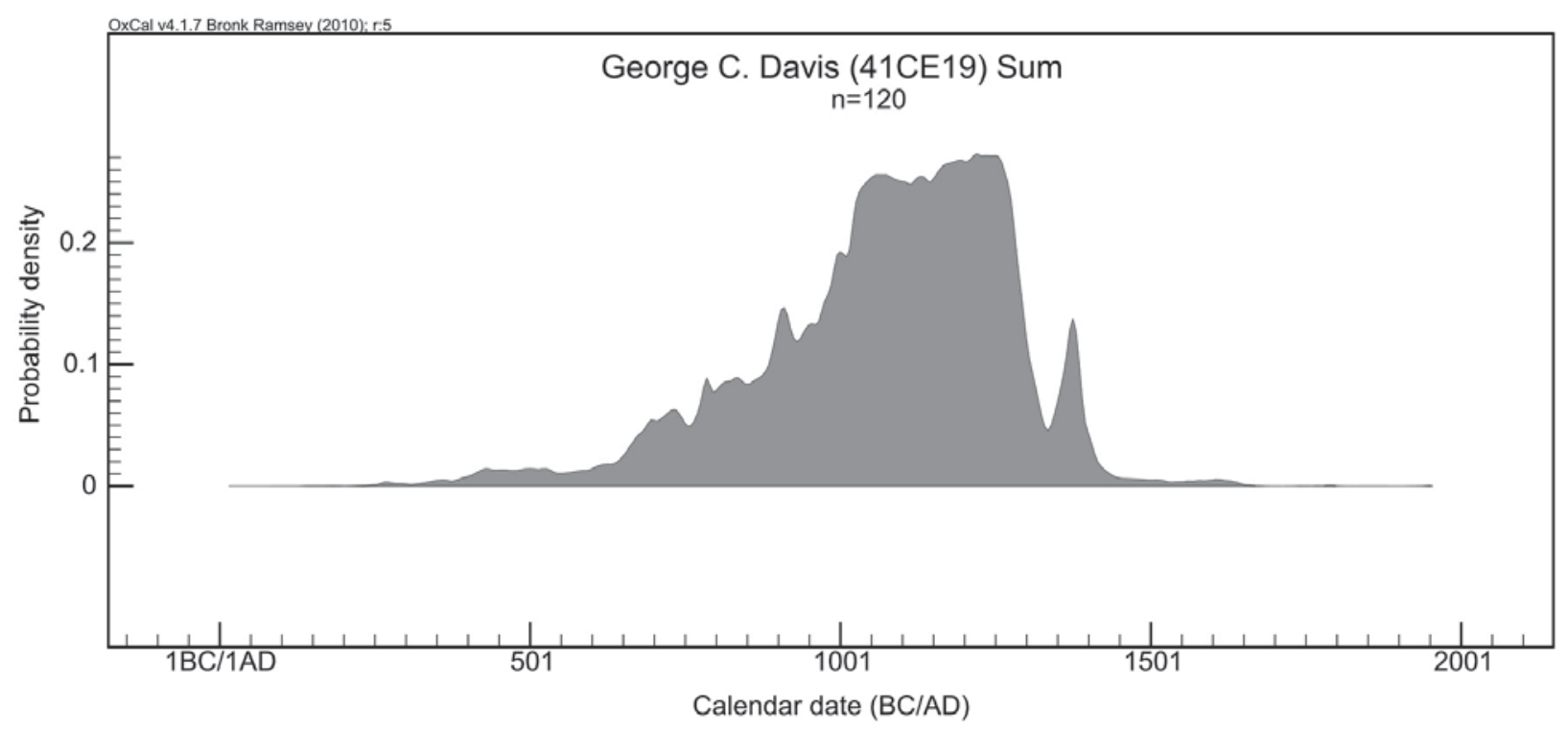

Figure 2. Summed probability distribution of previous calibrated radiocarbon dates from the George C. Davis site. Image provided courtesy of Robert Z. Selden Jr. 


\section{S. Roberts (41HE8)}

Four radiocarbon dates have been obtained from archaeological deposits at the M. S. Roberts site. One is from the mound excavations (Unit 1), and three are from off-mound habitation deposits southeast of the mound (Perttula et al. 2017:Figure 2) (Table 1). A fifth sample, unburned animal bone from Unit 1 $(37 \mathrm{~cm}$ bs), could not be dated because the bone failed in collagen extraction (Janet Niessner, February 26,2016 personal communication).

Table 1. Radiocarbon samples from the M. S. Roberts site (41HE8).

\begin{tabular}{lccc}
\hline $\begin{array}{l}\text { Provenience } \\
\text { (cm bs) }\end{array}$ & D-AMS No. & Radiocarbon age (B.P.) & $\begin{array}{c}\text { Calibrated age, 2 sigma } \\
\text { (A.D.)* }\end{array}$ \\
\hline ST 35, 40-60 & D-15386 & $1654 \pm 28$ & $340-425$ \\
Unit 2, 40-50 & D-15388 & $1673 \pm 26$ & $338-418$ \\
& & & $1282-1393$ \\
Unit 1, 54 & D-15382 & $651 \pm 28$ & $1387-1414$ \\
Unit 2, 20-30 & D-15387 & $572 \pm 22$ &
\end{tabular}

*IntCal13, from Reimer et al. 2013

Two dates on charred Carya sp. nutshell from 40-60 cm bs non-mound habitation deposits have 2 sigma calibrated age ranges of A.D. 338-418 and A.D. 340-425 (see Table 1), indicating that there are Woodland period archaeological deposits in this part of the site. The mean 2 sigma calibrated age range of these two radiocarbon dates is A.D. 335-422. Later ancestral Caddo archaeological deposits in the mound (unburned deer teeth in Unit 1, $54 \mathrm{~cm}$ bs, in Zone 3, see Perttula et al. 2016:Figure 4) and a nonmound area (charred nutshells in Unit 2, 20-30 cm bs) have 2 sigma calibrated age ranges of A.D. 12821393 and A.D. 1387-1414 (see Table 1). The mean 2 sigma calibrated age range of these two radiocarbon dates is A.D. 1294-1405, falling in the Middle Caddo period. Analysis of the decorated ceramic sherds in the M. S. Roberts assemblage, as well as the recovery of Haley variety long-stemmed Red River pipe sherds, is consistent with this calibrated age range (Perttula et al. 2016:Table 8).

\section{Roughcun (41TL95)}

The Roughcun site is in the Turkey Creek unit of Big Thicket National Preserve. It is situated on an upland toe slope in the Turkey Creek valley, and Turkey Creek is a small tributary stream in the Neches River basin. The archaeological deposits appear to be of Woodland period age (ca. 2500-1150 years B.P.) given that they contain Gary dart points and a number of Goose Creek Plain, var. unspecified ceramic sherds between 20-100 cm bs (Perttula and Nelson 2016).

The radiocarbon sample consisted of a single charred Carya sp. nutshell recovered from $40-60 \mathrm{~cm}$ bs in ST 1087. The conventional age of the nutshell is $1808 \pm 26$ years B.P. (D-AMS 15384). The calibrated 2 sigma age range of the sample is A.D. 131-318, falling squarely in the Woodland period.

\section{Summary and Conclusions}

Recent archaeological investigations in Cherokee, Henderson, and Tyler counties in East Texas recovered samples of charred organic remains or animal bone that has been submitted for radiocarbon analysis. The samples came from the George C. Davis (41CE19), Bowles Creek (41CE475), M. S. Roberts (41HE8), and Roughcun (41TL475); only the latter site is not within the Caddo archaeological area of East Texas. 
Woodland period radiocarbon dates ranging from A.D. 131-318 and A.D. 335-422 (mean calibrated age range of two samples) have been obtained from the Roughcun and M. S. Roberts site, the latter dates from non-mound archaeological deposits. The other newly obtained radiocarbon dates are from ancestral Caddo archaeological deposits. They include a 2 sigma calibrated age range of A.D. 1264-1290 on carbonized cane stem from a non-mound structure at George C. Davis, a 2 sigma calibrated age range of A.D. 1446-1632 from charred nutshell in a post hole at the Bowles Creek site, and a 2 sigma calibrated age range on two dates (on charred nutshell and unburned deer bone) of A.D. 1294-1405 from mound and non-mound habitation deposits at the M. S. Roberts site.

\section{References Cited}

Newell, H. P and A. D. Krieger

1949 The George C. Davis Site, Cherokee County, Texas. Memoir No. 5. Society for American Archaeology, Menasha, Wisconsin.

Perttula, T. K. and B. Nelson

2016 Archeological Survey of Selected Areas in the Big Thicket National Preserve, Hardin, Polk, and Trinity Counties, Texas. Center for Regional Heritage Research, Stephen F. Austin State University, Nacogdoches, in preparation.

Perttula, T. K. and K. Stingley

2017 Renewed Archaeological Investigations at the Bowles Creek (41CE475), Cornfield (41CE476), and Peach Orchard (41CE477) Sites in the Bowles Creek Valley, Cherokee County, Texas. Journal of Northeast Texas Archaeology 71, this volume.

Perttula, T. K., M. Walters, and B. Nelson

2017 The M. S. Roberts Site (41HE8): Archaeological Investigations at a Caddo Mound Site in the Upper Neches River Basin in East Texas. Journal of Northeast Texas Archaeology 71, this volume.

Reimer, P. J., E. Bard, A. Bayliss, J. W. Beck, P. G. Blackwell, C. Bronk Ramsey, C. E. Buck, H. Cheng, R. L. Edwards, M. Friedrich, P. M. Grootes, T. P. Guilderson, H. Haflidason, I. Hajdas, C. Hatte, T. J. Heaton, D. L. Hoffman, A. G. Hogg, K. A. Hughen, K. F. Kaiser, B. Kromer, S. W. Manning, M. Niu, R. W. Reimer, D. A. Richards, E. M. Scitt, J. R. Southon, R. A. Staff, C. S. M. Turney, and J. van der Plicht

2013 IntCal13 and Marine13 Radiocarbon Age Calibration Curves 0-50,000 Years Cal BP. Radiocarbon 55(4):1869-1887.

Selden, R. Z. Jr.

2012 Modeling Regional Radiocarbon Trends: A Case Study from the East Texas Woodland Period. Radiocarbon 54(2):239-265.

Selden, R. Z., Jr. and T. K. Perttula

2013a Radiocarbon Trends and the East Texas Caddo Tradition (ca. A.D. 800-1680). Southeastern Archaeology 32(1):85-96.

2013b Temporal Dynamics of East Texas Caddo Sites with 10 or More Radiocarbon Dates. Journal of Northeast Texas Archaeology 41:81-99. 